Article

\title{
Elicitation of the Allelopathic Potential of Rice by Methyl Salicylate Treatment
}

\author{
Babita Patni ${ }^{1}$, Sudhir Kumar Guru ${ }^{2}$, Marcello Iriti ${ }^{3, * \mathbb{C}}$ and Sara Vitalini ${ }^{3}$ \\ 1 High Altitude Plant Physiology Research Centre, H.N.B. Garhwal University (Central University), \\ Srinagar Garhwal 246174, Uttarakhand, India; babita28paatni@gmail.com \\ 2 Department of Plant Physiology, G.B. Pant University of Agriculture and Technology, Pantnagar 262310, \\ Uttarakhand, India; skguru123@yahoo.com \\ 3 Department of Agricultural and Environmental Sciences, Milan State University, 20133 Milan, Italy; \\ sara.vitalini@unimi.it \\ * Correspondence: marcello.iriti@unimi.it; Tel.: +39-02-50316766
}

Received: 2 October 2019; Accepted: 10 November 2019; Published: 14 November 2019

\begin{abstract}
Weed infestation is one of the most severe problems affecting rice production worldwide. Current weed control practices are either costly or pose a threat to the environment. The use of competitive rice genotypes seems to be a promising strategy. The aim of our study was to improve the allelopathic potential of three selected rice genotypes by foliar application of methyl salicylate (MeSA), a signaling molecule eliciting the plant defense response. Aqueous extracts of the shoots and roots of two competitive (UPR 2962-6-2-1 and Govind) and one non-competitive (UPR 2992-17-3-1) rice genotypes treated with MeSA solution at different concentrations (1 mM, $2 \mathrm{mM}$, and $3 \mathrm{mM})$ showed phytotoxic effects on the growth of the weed Echinochloa colona. Specifically, shoot and root extracts obtained from the competitive rice genotypes similarly decreased both the E. colona germination rate ( $9 \%$ to $44.5 \%$ ) and the length of its roots and shoots (11\% to $48 \%$ ). Extracts of the non-competitive rice genotype showed a similar trend but lower effects, inhibiting the E. colona germination up to $32 \%$ and reducing the growth of the weed roots and shoots by $6-23.5 \%$ and $7-28 \%$, respectively, according to the increasing MeSA concentrations. High-performance liquid chromatography (HPLC) analysis demonstrated an increase in different allelopathic phenolic acids in the three rice genotypes in response to MeSA treatments. Among the detected compounds, vanillic and protocatechuic acids showed the greatest differences compared to controls with values up to 2.1-fold higher in shoots of the two competitive UPR-2962-6-2-1 and Govind rice genotypes, while their roots were characterized by the greatest increases of 8-hydroxyquinoline (8.2-fold) and protocatechuic acid (1.7-fold). Differently, non-competitive genotype UPR 2992-17-3-1 showed the highest increase for gallic acid (2.2-fold) in shoots and for p-hydroxybenzoic acid (2.4-fold) in roots. Lastly, MeSA was found to improve the competitiveness of rice genotypes without any detrimental effect on the host plant.
\end{abstract}

Keywords: allelochemicals; elicitors; Oryza sativa; paddy; phenolics; phytotoxicity

\section{Introduction}

Weeds are one of the major threats to farm productivity and their management is an ever-present challenge. Chemical approach is becoming increasingly problematic, both in terms of environmental pollution and herbicide resistance. Among the alternative strategies, allelopathy integrated with the existing agronomic solutions can be a tool to give greater sustainability to agro-production systems. Allelopathy is defined as the beneficial or detrimental influence of one organism on the growth and development of other organisms by the production of chemical compounds known as allelochemicals [1]. They are mainly plant secondary metabolites (e.g., alkaloids, flavonoids, glucosinolates, hydroxamic 
acids, phenols, salicylates, terpenoids) released by leaching, decomposition, volatilization, and root exudation or microbe decomposition products [1,2]. Allelopathy is a natural survival process and has been used to reduce the competition from neighboring plants in agriculture since ancient times for its positive effects such as weed control, crop protection, and crop re-establishment [1].

In sustainable agriculture, the possibility of incorporating allelopathic traits into genotypes to enhance their competitiveness is worth exploring [3]. The competitiveness provided by allelopathic genotypes could reduce the burden of using conventional herbicides, thus reducing the inputs of agrochemicals [4]. Rice is one of the most important crops in the world and its allelopathy has attracted great attention, as the allelopathic potential of some genotypes against one or more paddy weeds has been demonstrated [5]. Since then, the selection of allelopathic rice germplasm has been carried out in many countries [6-16]. Several main and epistatic quantitative loci have been identified responsible for allelopathy in rice [17]. However, instead of developing new competitive genotypes, allelopathy can be more useful to screen the existing germplasm for allelopathic crop genotypes [18]. It was shown that some rice cultivars were able to suppress the growth of various paddy common weeds, including the Echinochloa species that cause severe yield losses, showing greater allelopathic potential than others [19-25].

Previous works hypothesized that allelopathy is an actively inducible defense mechanism and that plant signaling compounds are potentially valuable in its regulation [26]. Among them, salicylic acid (SA) plays a key role in plant defense [27]. It can activate many stress-related genes and the release of allelochemicals [26,28]. The application of SA to different plant species was sufficient to invoke disease resistance [29]. However, it has been shown that its methyl ester, i.e., MeSA, is more effective when applied exogenously [30]. MeSA is an organic ester naturally produced by many plants, particularly wintergreens. It can be manufactured synthetically and it is used as a flavoring agent in foods, beverages, and liniments [31].

In this study, 10 rice genotypes were screened for their allelopathic potential. Then, two competitive and one non-competitive genotypes were selected and further investigated for the changes in their allelopathic potential after the exogenous application of MeSA.

\section{Materials and Methods}

\subsection{Chemicals}

Standards of caffeic acid (CAF), p-coumaric acid (PC), gallic acid (GAL), p-hydroxybenzoic acid (PHB), 8-hydroxyquinoline (HQ), protocatechuic acid (PRO), syringic acid (S), and vanillic acid (V) were purchased from Sigma-Aldrich (Bangalore, India). Diethyl ether, methanol, and acetic acid, as well as MeSA, were also obtained from Sigma-Aldrich (Bangalore, India).

\subsection{Seeds}

The seeds of 10 rice genotypes, namely of Pant Dhan-16, UPR2916-211, Pant Sankar Dhan-3, UPR-2919-14-1-1, UPR-2962-6-2-1, UPR-2992-17-3-1, UPRI 2005-15, UPR 2805-14-12, V3R11, and Govind, were used.

The seeds of weeds belonging to different botanical families, such as Alternanthera sessilis (L.) R.Br. ex DC. (Amaranthaceae), Caesulia axillaris Roxb. (Asteraceae), Cyperus iria L. (Cyperaceae), Echinochloa crus-galli (L.) P.Beauv. (Poaceae), Echinochloa colona (L.) Link (Poaceae), Paspalum distichum L., and Ammannia L. species (Lythraceae), were chosen for the first part of the experimental design.

Before use, all seeds were surface-sterilized with $70 \%$ ethanol by shaking for $15 \mathrm{~min}$, then rinsed with distilled water three times and sown in germination trays. After five days, the germinated seeds were transplanted in plastic pots $(7 \mathrm{~cm} \times 10 \mathrm{~cm})$, kept in a growth chamber at $24-26{ }^{\circ} \mathrm{C}$ with a photoperiod of 12-h light and 12-h dark, watered, and fertilized with Hoagland nutrient solution every two days. 


\subsection{Experimental Design}

The experiment was carried out through a split-plot design with three replicates at Norman E. Borlaug Crop Research Center, G.B. Pant University of Agriculture and Technology, Uttarakhand, India. The main plots included two conditions, weedy (weeds were not removed) and weed-free (weeds were removed by hand whenever they appeared), while subplots included all rice genotypes [32].

\subsection{Methyl Salicylate Treatment}

Rice seedlings were treated with MeSA as described by Bi et al. [18]. At the two-, four-, and six-leaf stage, they were sprayed with $1 \mathrm{mM}, 2 \mathrm{mM}$, and $3 \mathrm{mM}$ MeSA solution and left in growth chamber for $48 \mathrm{~h}$. Control plants were not treated with MeSA.

\subsection{Morphological Trait Measurements}

Morphological parameters, such as plant height, number of leaves, and leaf area, in addition to dry matter, of all the rice genotypes cultivated under weedy and weed-free conditions were recorded both at flowering and maturity stages [32].

\subsection{Aqueous Extraction}

Based on the collected data, two competitive and one non-competitive rice genotypes were selected. Then, $2 \mathrm{~g}$ of their shoots and roots were chopped and extracted with $10 \mathrm{~mL}$ of water for two days. Each residue was re-extracted by $10 \mathrm{~mL}$ of water and the two extracts were pooled together, filtered, and stored at $4{ }^{\circ} \mathrm{C}$ until use. Aqueous extracts were also obtained from the control plants.

\subsection{Phytotoxic Activity}

Seeds from E. colona, a cosmopolitan weed common in rice fields, were used to assess the in vitro phytotoxic activity of the aqueous extracts. Germination percentage, root, and shoot lengths of E. colona seedlings grown in petri dishes were detected seven days after the treatment [32].

\subsection{Determination of the Phenolic Acid Content}

The aqueous extracts were partitioned against equal volume of diethyl ether three times. The obtained fractions were combined and evaporated to dryness at room temperature and reduced pressure. Each residue was dissolved in $2 \mathrm{~mL}$ of methanol and filtered through a $0.22-\mu \mathrm{m}$ membrane filter (Millipore HVLP01300, Merk, Massachusetts, USA). The phenolic compounds in the filtrate were analyzed using a DIONEX Ultimate 3000 HPLC system equipped with a reverse phase C18 column, detector, and autosampler to monitor the absorbance of elution at $254 \mathrm{~nm}$. The solvent system was $70 \%$ methanol and $2 \%$ acetic acid. Ten microliters of each sample were injected at a flow rate was $1.0 \mathrm{~mL} / \mathrm{min}$ and temperature of $32^{\circ} \mathrm{C}$. Pure compounds were used as standards and phenolic acids were identified by comparison of retention time and UV spectrum.

\subsection{Statistical Analysis}

The statistical analysis for all the parameters was carried out using analysis of variance for split-plot design, with means being tested at $p>0.05$ using an STPR software designed at the Department of Mathematics, Statistics, and Computer Science, CBSH, G.B. Pant University of Agriculture and Technology.

\section{Results and Discussion}

\subsection{Morphological Traits}

Plant height, leaf number, leaf area, and dry matter of 10 rice genotypes were recorded at flowering and maturity stages both under weedy and weed-free conditions (Table 1). 
Table 1. Plant height, leaf number, leaf area, and dry matter of 10 rice genotypes cultivated in weedy (W) and weed-free (WF) plots at flowering and maturity stages.

\begin{tabular}{|c|c|c|c|c|c|c|c|c|c|c|c|c|c|c|c|c|}
\hline \multirow{3}{*}{ Genotypes } & \multicolumn{4}{|c|}{ Plant Height (cm) } & \multicolumn{4}{|c|}{ Leaf No. } & \multicolumn{4}{|c|}{ Leaf Area $\left(\mathrm{cm}^{2}\right)$} & \multicolumn{4}{|c|}{ Dry Matter $\left(\mathrm{g} \mathrm{m}^{-1}\right)$} \\
\hline & \multicolumn{2}{|c|}{ Flowering } & \multicolumn{2}{|c|}{ Maturity } & \multicolumn{2}{|c|}{ Flowering } & \multicolumn{2}{|c|}{ Maturity } & \multicolumn{2}{|c|}{ Flowering } & \multicolumn{2}{|c|}{ Maturity } & \multicolumn{2}{|c|}{ Flowering } & \multicolumn{2}{|c|}{ Maturity } \\
\hline & WF & $\mathbf{W}$ & WF & W & WF & $\mathbf{W}$ & WF & W & WF & $\mathbf{W}$ & WF & $\mathbf{W}$ & WF & W & WF & W \\
\hline PD-16 & 100.8 & 91.3 & 102.0 & 101.5 & 32.3 & 31.8 & 15.8 & 17.3 & 1442.3 & 1372.3 & 324.2 & 339.5 & 15.6 & 14.6 & 25.1 & 20.8 \\
\hline UPR2916-211 & 93.3 & 84.8 & 104.8 & 100.6 & 29.1 & 32.2 & 22.1 & 20.0 & 1505.0 & 1466.6 & 649.6 & 524.3 & 19.8 & 17.1 & 25.5 & 22.3 \\
\hline PSD-3 & 103.8 & 93.1 & 105.6 & 102.0 & 34.6 & 39.8 & 27.3 & 22.1 & 1784.3 & 1574.3 & 69.3 & 84.6 & 15.9 & 13.6 & 22.0 & 19.2 \\
\hline UPR-2919-14-1-1 & 92.8 & 84.0 & 101.3 & 94.60 & 39.0 & 44.8 & 24.3 & 18.3 & 1900.6 & 1669.6 & 326.0 & 72.3 & 19.3 & 17.4 & 29.8 & 27.6 \\
\hline UPR-2962-6-2-1 & 88.8 & 88.3 & 102.3 & 101.6 & 32.3 & 42.6 & 22.0 & 22.3 & 1151.6 & 1087.3 & 889.6 & 840.3 & 18.1 & 16.9 & 33.6 & 31.1 \\
\hline UPR-2992-17-3-1 & 94.0 & 91.3 & 103.1 & 102.1 & 35.1 & 49.5 & 23.1 & 16.6 & 1497.6 & 956.0 & 39.3 & 70.6 & 18.5 & 15.3 & 23.3 & 18.7 \\
\hline UPRI-2005-15 & 101.5 & 84.6 & 105.3 & 102.3 & 36.0 & 37.0 & 19.0 & 16.6 & 2002.3 & 1896.3 & 265.3 & 169.6 & 13.7 & 10.6 & 25.6 & 26.6 \\
\hline UPR-2805-14-12 & 77.5 & 80.3 & 93.6 & 86.1 & 35.6 & 36.0 & 24.8 & 21.5 & 1380.0 & 823.6 & 417.3 & 387.6 & 8.7 & 6.9 & 24.8 & 21.2 \\
\hline V3R11 & 89.8 & 82.1 & 99.8 & 98.3 & 46.8 & 49.1 & 27.8 & 26.0 & 1131.0 & 1107.3 & 681.3 & 814.0 & 16.9 & 15.3 & 26.1 & 22.5 \\
\hline Govind & 82.5 & 79.1 & 84.6 & 83.3 & 36.3 & 38.8 & 21.5 & 21.3 & 984.3 & 949.3 & 157.3 & 326.0 & 18.2 & 17.4 & 28.4 & 26.7 \\
\hline $\mathrm{SEM} \pm$ & \multicolumn{2}{|c|}{0.63} & \multicolumn{2}{|c|}{0.72} & \multicolumn{2}{|c|}{0.45} & \multicolumn{2}{|c|}{0.75} & \multicolumn{2}{|c|}{0.13} & \multicolumn{2}{|c|}{0.38} & \multicolumn{2}{|c|}{0.17} & \multicolumn{2}{|c|}{0.30} \\
\hline $\operatorname{LSD}(p \leq 0.05)$ & \multicolumn{2}{|c|}{3.74} & \multicolumn{2}{|c|}{4.31} & \multicolumn{2}{|c|}{26.94} & \multicolumn{2}{|c|}{4.49} & \multicolumn{2}{|c|}{82.29} & \multicolumn{2}{|c|}{22.91} & \multicolumn{2}{|c|}{1.04} & \multicolumn{2}{|c|}{1.79} \\
\hline Genotypes (G) & \multicolumn{2}{|c|}{6.06} & \multicolumn{2}{|c|}{3.00} & \multicolumn{2}{|c|}{6.42} & & & 97. & & 55 & & & & & \\
\hline Weed $(W)$ & 8. & & & & & & & & 138 & & 78 & & & & & \\
\hline $\mathrm{G} \times W$ & 10 & & & & & & & & 188 & & 83 & & & & & \\
\hline
\end{tabular}


The decrease of plant height under weedy conditions ranged from $0.56 \%$ to $16.7 \%$ and from $0.5 \%$ to $8 \%$ at the time of flowering and maturity, respectively. Rice genotypes UPR-2962-6-2-1 (0.56\%), UPR-2992-17-3-1 (2.9\%), and Govind (4.12\%) showed the lowest decrease compared to other genotypes $(\geq 8.6 \%)$ at flowering. A similar trend $(0.7 \%, 1 \%$, and $1.5 \%)$ was recorded for the three genotypes at maturity (Table 1). Therefore, these rice genotypes can be considered competitive, unlike the non-competitive genotypes, showing a greater decrease in plant height under weedy conditions compared to the weed-free conditions.

Leaf number increased in the range $1.1-29 \%$ at flowering stage under weedy conditions in comparison with the weed-free conditions. UPR-2992-17-3-1 and UPR-2962-6-2-1 were genotypes showing the greatest difference ( $24 \%$ and $29 \%$, respectively). At maturity, an opposite trend was observed. The leaves decreased from 1\% to 39\% in Govind and UPR-2992-17-3-1 rice genotypes, respectively. This decrease likely occurred because at the beginning of seed setting, the maximum amount of photosynthates were diverted toward the maturing grains (Table 1).

Among other factors, the leaf area that can confer competitive ability against weeds. Plants with a higher leaf area capture more sunlight, thus shading neighboring growing weeds and lowering their photosynthetic rate [33-35]. Therefore, greater development of the leaf area in weedy conditions was a significant trait which was recorded at the end of the experiment (Table 1). At flowering, in contrast to the increase in leaf number, leaf area decreased under weedy conditions. The detected values ranged from $2.1 \%$ to $40 \%$ less than those measured under weed-free conditions. The genotypes UPR-2916-211 (2.5\%), UPR-2962-6-2-1 (5.5\%), V3R11 (2.1\%), and Govind (3.5\%) showed the lowest decrease, while the highest reductions were found in UPR-2992-17-3-1 (36\%) and UPR 2805-14-12 (40\%). At maturity, this indicator did not show a definite trend, with half of the genotypes characterized by a lower leaf area. The other half was characterized by a greater leaf area compared to plants grown in the absence of weeds (Table 1$)$.

The dry matter was also detected at the flowering and maturity stages to obtain a clear picture of accumulated biomass under weedy and weed-free conditions. At both stages, dry matter decreased in weedy conditions. The lowest losses were noted in genotypes UPR-2962-6-2-1 (6.6\% and 7.4\%, respectively) and Govind ( $4.3 \%$ and $5.9 \%$, respectively), thus delineating their competitive nature.

In agreement with previous reports, these results corroborated that the rice genotypes possess different competitiveness against weed populations [8,9,13,36]. For example, Dilday et al. [8] screened approximately 5000 rice genotypes for competitiveness against Heteranthera limosa (Sw.) Willd. Among them, about $4 \%$ demonstrated some allelopathic activity. Jung et al. [37] reported the allelopathic potential of 114 rice residues on weed emergence $(-51.45 \%)$, height $(-39.75 \%)$, and dry weight $(-5.13 \%)$ of E. crus-galli. Finally, our findings confirmed that Govind and UPR 2962-6-2-1 genotypes are the most competitive on emergent weeds in the early stages of their growth [32].

\subsection{Weed Population}

Weed populations were checked 15 days after transplanting of the germinated seeds and their numbers were expressed per square meter. The occurrence of A. sessilis, C. axillaris, C. iria, E. crus-galli, E. colona, P. distichum, and Ammannia spp. was recorded. The lowest number of weeds was found in the genotypes UPR-2962-6-2-1 and Govind, which were able to suppress six out of seven weeds compared to the other eight rice genotypes (data not shown). This reduction can be ascribed to their competitiveness, probably exerted in the form of a better canopy development and nutrient uptake $[33,38]$. Moreover, it can be assumed that the two genotypes produce higher amounts of phenolic compounds, allelochemicals that can suppress weed growth [2].

\subsection{Methyl Salicylate Treatments}

A second experiment was carried out to study the effect of MeSA treatments on the competitiveness of rice genotypes. Based on the above parameters and percent reduction in yield (data not shown), 
three rice genotypes, two competitive (UPR-2962-6-2-1 and Govind) and one (UPR-2992-17-3-1) non-competitive, were selected.

Their aqueous extracts showed higher phytotoxic effects on the growth of E. colona than those from control plants (Table 2). The shoot extracts the two competitive genotypes, UPR-2962-6-2-1 and Govind, decreased E. colona seed germination, with values ranging from $9.2 \%$ to $42.5 \%$ and from $13 \%$ to $44.5 \%$, respectively, while the root extracts ranged from $11.4 \%$ to $41.4 \%$ and from $16.2 \%$ to $48 \%$. The shoot extracts from the non-competitive rice genotype UPR-2992-17-3-1 decreased E. colona germination by $10.4 \%, 19.2 \%$, and $26.2 \%$ at $1 \mathrm{mM}, 2 \mathrm{mM}$, and $3 \mathrm{mM} \mathrm{MeSA}$, respectively, and root extracts decreased germination by $9.9 \%, 16.7 \%$, and $31.7 \%$.

Table 2. Effects of shoot and root extracts obtained from rice genotypes treated with $1 \mathrm{mM}, 2 \mathrm{mM}$, and $3 \mathrm{mM}$ concentrations of methyl salicylate (MeSA) on percent germination, root and shoot length of the weed Echinochloa colona.

\begin{tabular}{|c|c|c|c|c|c|c|c|}
\hline \multirow[t]{2}{*}{ Genotypes } & \multirow[t]{2}{*}{$\begin{array}{c}\text { MeSA } \\
(\mathrm{mM})\end{array}$} & \multicolumn{2}{|c|}{$\begin{array}{c}\text { E. colona } \\
\text { Germination }(\%)\end{array}$} & \multicolumn{2}{|c|}{$\begin{array}{l}\text { E. colona Root } \\
\text { Length }(\mathrm{cm})\end{array}$} & \multicolumn{2}{|c|}{$\begin{array}{l}\text { E. colona Shoot } \\
\text { Length }(\mathrm{cm})\end{array}$} \\
\hline & & $\begin{array}{l}\text { Shoot } \\
\text { extract }\end{array}$ & $\begin{array}{c}\text { Root } \\
\text { extract }\end{array}$ & $\begin{array}{l}\text { Shoot } \\
\text { extract }\end{array}$ & $\begin{array}{c}\text { Root } \\
\text { extract }\end{array}$ & $\begin{array}{l}\text { Shoot } \\
\text { extract }\end{array}$ & $\begin{array}{c}\text { Root } \\
\text { extract }\end{array}$ \\
\hline \multirow{4}{*}{ UPR-2992-17-3-1 } & Control & 86.3 & 77.7 & 6.8 & 6.8 & 5.8 & 5.9 \\
\hline & 1 & 77.3 & 70.0 & 6.1 & 6.4 & 5.1 & 5.5 \\
\hline & 2 & 69.7 & 64.7 & 5.5 & 5.9 & 4.5 & 5.3 \\
\hline & 3 & 63.7 & 53.0 & 5.2 & 5.4 & 4.2 & 5.1 \\
\hline \multirow{4}{*}{ UPR-2962-6-2-1 } & Control & 65.0 & 61.0 & 6.4 & 6.7 & 5.7 & 5.8 \\
\hline & 1 & 59.0 & 54.0 & 5.5 & 5.5 & 5.0 & 5.1 \\
\hline & 2 & 46.7 & 42.3 & 4.9 & 4.7 & 4.0 & 4.6 \\
\hline & 3 & 38.0 & 35.7 & 4.1 & 4.2 & 3.4 & 3.5 \\
\hline \multirow{4}{*}{ Govind } & Control & 58.3 & 57.7 & 5.9 & 5.9 & 5.5 & 5.8 \\
\hline & 1 & 50.7 & 48.3 & 5.1 & 5.4 & 4.8 & 5.3 \\
\hline & 2 & 43.3 & 39.0 & 4.4 & 4.7 & 4.1 & 4.6 \\
\hline & 3 & 32.3 & 30.0 & 4.0 & 4.2 & 3.3 & 3.6 \\
\hline \multicolumn{2}{|c|}{$\operatorname{LSD}(p \leq 0.05)$} & 4.04 & 2.83 & 0.80 & 0.81 & 0.80 & 0.64 \\
\hline \multicolumn{2}{|c|}{ Genotypes $(\mathrm{G})$} & 5.50 & 3.84 & 1.08 & 1.11 & 1.09 & 0.87 \\
\hline \multicolumn{2}{|c|}{ Methyl salicylate (MeSA) } & 6.35 & 4.44 & 1.25 & 1.28 & 1.26 & 1.00 \\
\hline \multicolumn{2}{|c|}{$\mathrm{G} \times \mathrm{MeSA}$} & 11.0 & 7.69 & 2.17 & 2.22 & 2.18 & 1.74 \\
\hline
\end{tabular}

The reduction of the E. colona root and shoot length ranged from $10.1 \%$ to $23.5 \%$ and from $12.1 \%$ to $27.6 \%$, respectively, due to the action of the UPR-2992-17-3-1 shoot extract, while the root extract increased their inhibition from $5.8 \%$ to $20.5 \%$ and from $6.7 \%$ to $13.5 \%$ with the increasing concentration of MeSA. It is evident that the treatment with the signaling compound increased the competitiveness of the non-competitive genotype over the control.

The shoot and root extracts from the competitive genotype UPR-2962-6-2-1 after treatment with $3 \mathrm{mM}$ MeSA reached the maximum inhibition of E. colona root and shoot length with similar values equal to $35.9 \%$ and $40.3 \%$ and $37.3 \%$ and $39.6 \%$, respectively. Similarly, for the shoot and root extracts of the genotype Govind, the maximum inhibition of E. colona root and shoot length was $32.2 \%$ and $40 \%$ and $28.8 \%$ and $37.9 \%$, respectively.

Bioassay results showed that both the competitive and non-competitive rice genotypes enhanced their phytotoxicity against $E$. colona after treatment with MeSA. These results are in accordance with the results of Bi et al. [26], who reported that treatments with the signaling compounds MeSA and methyl jasmonate increased the phytotoxicity of allelopathic and non-allelopathic rice genotypes against the Echinochloa species.

\subsection{Phenolic Acids}

The phenolic acid content of the genotypes UPR-2992-17-3-1, UPR-2962-6-2-1, and Govind after treatment with $1 \mathrm{mM}, 2 \mathrm{mM}$, or $3 \mathrm{mM}$ MeSA was analyzed by high-performance liquid chromatography 
(HPLC) using syringic acid (S), vanillic acid (V), p-hydroxybenzoic acid (PHB), p-coumaric acid (PC), caffeic acid (CAF), protocatechuic acid (PRO), 8-hydroxyquinoline (HQ), and gallic acid (GAL) as standards (Table 3).

Table 3. Retention time of the phenolic acid standards.

\begin{tabular}{cc}
\hline Phenolic Acid & Retention Time (min) \\
\hline Syringic acid (S) & 9.9 \\
Vanillic acid (V) & 7.1 \\
$p$-Hydroxybenzoic acid (PHB) & 9.4 \\
p-Coumaric acid (PC) & 13.0 \\
Caffeic acid (CAF) & 11.6 \\
Protocatechuic acid PRO) & 5.57 \\
8-Hydroxyquinoline (HQ) & 4.8 \\
Gallic acid (GAL) & 3.6 \\
\hline
\end{tabular}

Phenolic acids with different structures and modes of action show variable phytotoxic activity [39]. All phenolic acids detected in the three rice genotypes after MeSA exposure are among the main phytotoxic compounds isolated from the aqueous extracts of allelopathic plants $[39,40]$. They demonstrated significant inhibition of the Lactuca sativa seed germination compared to the control at $10 \mathrm{ppm}$ or at $1 \mathrm{mM}$ and $2 \mathrm{mM}$ concentrations [39]. Differently, Bravo and coworkers [41] reported that some acids, namely p-hydroxybenzoic, vanillic, gallic, and caffeic acids, have not proved capable of significantly reducing L. sativa germination both at $100 \mu \mathrm{g} / \mathrm{mL}$ and $250 \mu \mathrm{g} / \mathrm{mL}$. On the contrary, caffeic acid showed a particular behavior stimulating seedling growth, particularly the root elongation of L. sativa, in the concentration range $50-500 \mu \mathrm{g} / \mathrm{mL}$ [41]. Lastly, the phytotoxicity of the compounds involved in allelopathic effects depends upon the target species and, overall, their chemical interference is probably based upon a combination of phytotoxic metabolites. Studies on phenolic acid mixtures have shown that individual components can be additive when being evaluated for phytotoxic affects. However, further research is still needed to find evidence for their synergistic activities [41].

In our work, all MeSA treatments enhanced the production of these compounds in the analyzed samples. In particular, the 2-mM concentration of MeSA had the largest effect. In the shoot extracts of competitive genotype UPR-2962-6-2-1, the resulting increase of S, V, PHB, PC, CAF, PRO, and GAL was 1.8-, 2.1-, 2-, 1.6-, 1.5-, 2.1-, and 1.6-fold, respectively, compared to control (Figure 1a). In Govind genotype S, V, PHB, PC, PRO, and HQ increased by 1.8-, 2.1-, 1.6, 1.5-, 1.9-, and 1.8-fold, respectively (Figure 1b).

The root extracts of UPR-2962-6-2-1 reported an increment of 1.6-, 1.8-, 1.6-, 1.5-, 1.5-, 1.6-, 8.2-, and 1.6-fold in the levels of all eight considered compounds, respectively (Figure 2a). The concentrations of S, V, PHB, PC, PRO, HQ, and GAL increased by 1.4-, 1.6-, 1.5-, 1.3-, 1.7-, 1.6-, and 1.5-fold in Govind roots, respectively (Figure $2 b$ ). An increase in phenolic acids also occurred in the non-competitive genotype UPR-2992-17-3-1 (Figure 1c). Though PC reached the highest levels of concentration in the shoots after all three MeSA treatments, HQ and GAL recorded the greatest differences compared to the control with values up to 2- and 2.2-fold higher at 2-mM MeSA, respectively (Figure 1c). A similar effect was detected on the phenolic content of the root extracts characterized by S, V, PHB, PC, HQ, and GAL compounds. Their concentrations reported an increase of 1.9-, 1.4-, 2.4-, 1.6-, 2.3-, and 2.1-fold, respectively (Figure 2c). 


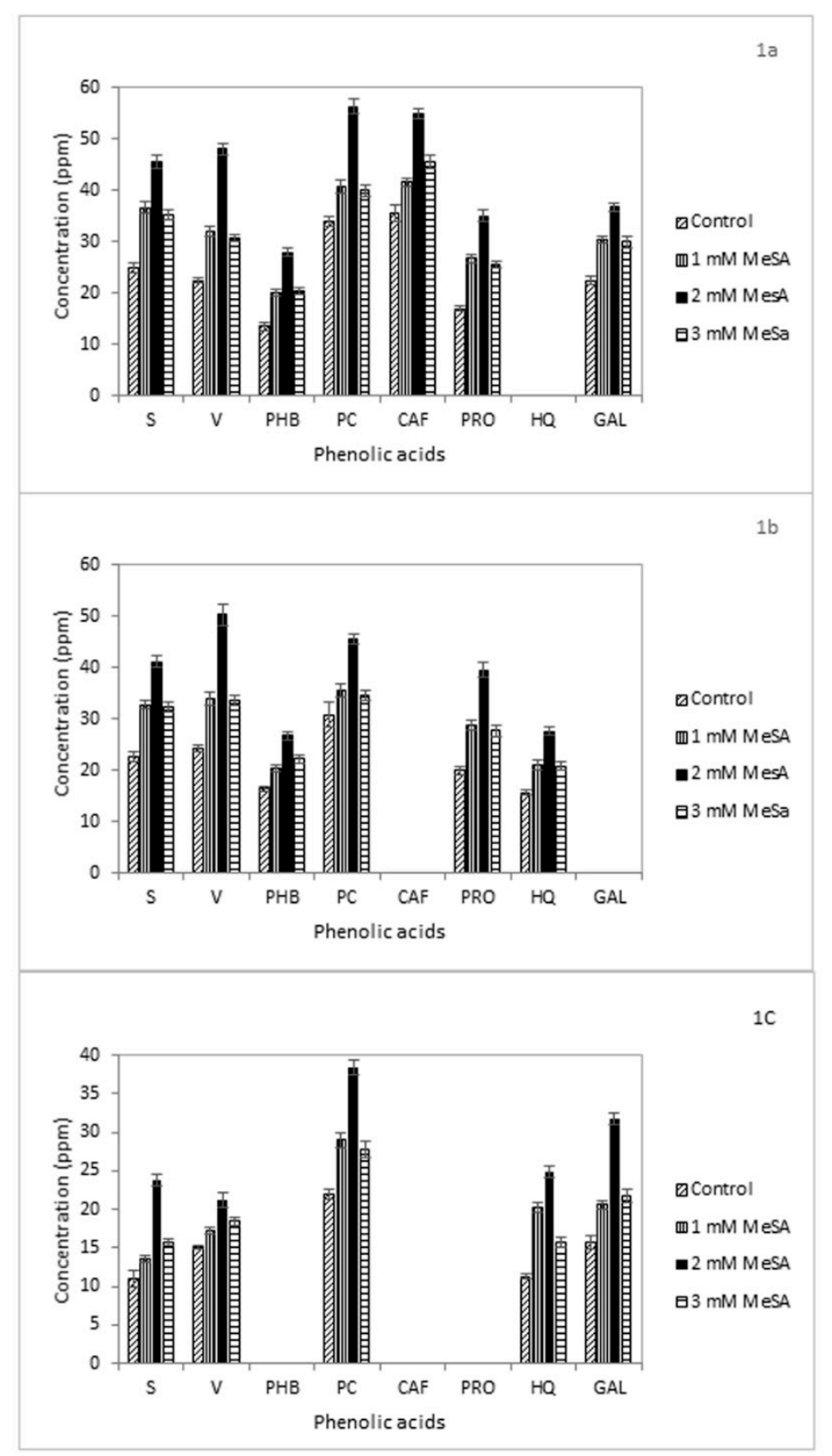

Figure 1. Concentration (ppm) of phenolic acids in the aqueous shoot extracts of the rice genotypes: (a) Govind; (b) UPR-2962-5-2-1, and (c) UPR-2992-17-3-1 after treatment with methyl salicylate (MeSA, $1 \mathrm{mM}, 2 \mathrm{mM}$, or $3 \mathrm{mM}$ ). The values are means from three replicates. $\mathrm{S}=$ syringic acid, $\mathrm{V}=$ vanillic acid, $\mathrm{PHB}=$ p-hydroxybenzoic acid, $\mathrm{PC}=p$-coumaric acid, $\mathrm{CAF}=$ caffeic acid, $\mathrm{PRO}=$ protocatechuic acid, $\mathrm{HQ}=8$-hydroxyquinoline, and GAL = gallic acid. 


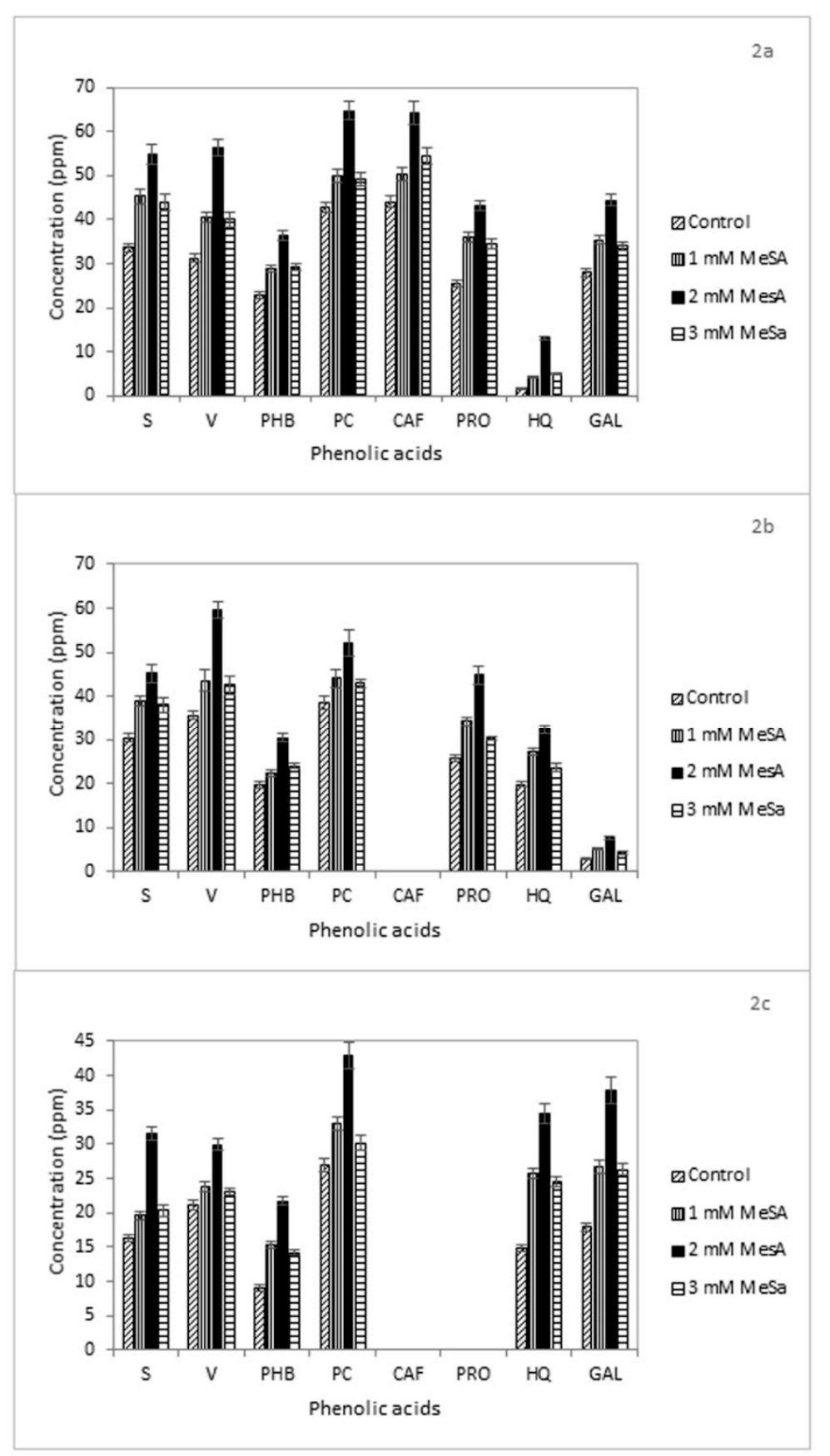

Figure 2. Concentration (ppm) of phenolic acids in the aqueous root extracts of the rice genotypes: (a) UPR-2962-5-2-1, (b) Govind, and (c) UPR-2992-17-3-1 after treatment with methyl salicylate (MeSA, $1 \mathrm{mM}, 2 \mathrm{mM}$, or $3 \mathrm{mM}$ ). The values are means from three replicates. $\mathrm{S}=$ syringic acid, $\mathrm{V}=$ vanillic acid, $\mathrm{PHB}=p$-hydroxy benzoic acid, $\mathrm{PC}=p$-coumaric acid, $\mathrm{CAF}=$ caffeic acid, $\mathrm{PRO}=$ protocatechuic acid, $\mathrm{HQ}=8$-hydroxyquinoline, and GAL = gallic acid.

In all genotypes, the phenolic acid amount recorded after treatments with $1 \mathrm{mM}$ MeSA was at par with that at $3 \mathrm{mM}$ MeSA, both in shoots and roots. It is likely that $1 \mathrm{mM}$ is a low-dose treatment, whereas $3 \mathrm{mM}$ could be slightly phytotoxic or somehow repress the phenolic acid biosynthesis in plant. We can also speculate that a negative feedback regulation of salicylates occurs in rice.

Similar increments in phenolic acid contents after the application of signaling compounds were shown by Bi et al. [26] and An et al. [30]. These results suggest that MeSA exerted an effect on the phytotoxic potential of rice genotypes in which the allelopathic activity against E. colona increased 
in response to its foliar application, both in competitive and non-competitive genotypes. This increment could be attributed to the well-known role of salicylic acid as an elicitor of the plant's own defense mechanisms toward insect and pathogen attacks, including the increased biosynthesis of allelochemicals [42]. Hence, MeSA can be developed to enhance the allelopathic potential of the crop plants. It has been documented that the weeds compete with the host crop for area, nutrients, water, and sunlight, and this competition results in decreased growth and yield losses in the host plant. These losses can be minimized by the use of competitive genotypes. Moreover, treatments with signaling compounds such as MeSA can further increase the competitiveness of the genotypes against weed species by stimulating the accumulation of the allelochemicals such as phenolic acids.

Treatments of rice plants with MeSA improved their growth, productivity, and competitiveness against weeds. Therefore, the use of elicitors in effective concentrations can be developed to enhance the allelopathic potential of the crops, as well as their yield and resilience. Boosting the production of allelochemicals in crop plants could represent a promising strategy in weed control as an alternative to the intensive use of conventional herbicides.

\section{Conclusions}

Chemical weed control is problematic and developing an alternative and sustainable approach is pivotal. Here, we applied an elicitor to improve the allelopathic potential of rice against weeds. Treatments also raised the levels of allelochemicals. This study opens a new perspective on the use of systemic acquired resistance (SAR) elicitors or plant activators in weed control, stimulating the plant's own defense mechanisms (innate immunity). This study impacts the field of herbicides, contributing to the reduced use of conventional herbicides, as well as the risk of selecting resistant weeds (elicitors stimulate a multigenic system in the crop species and do not exert any selective pressure on the weeds).

Author Contributions: Conceptualization, B.P., S.K.G., S.V. and M.I.; Methodology, B.P. and S.K.G.; Validation, B.P., S.K.G., S.V. and M.I.; Formal Analysis, B.P. and S.K.G.; Investigation, B.P., S.K.G., S.V. and M.I.; Resources, S.K.G. and M.I.; Data Curation, B.P., S.K.G., S.V. and M.I.; Writing-Original Draft Preparation, B.P. and S.K.G.; Writing-Review \& Editing, S.V. and M.I.; Supervision, S.V. and M.I.; Funding Acquisition, S.K.G. and M.I.

Funding: This research received no external funding.

Acknowledgments: Authors acknowledge the support received from G. B. Pant University of Agriculture and Technology and the CSIR grant for purchasing chemicals and all necessary material for completion of this research.

Conflicts of Interest: The authors declare no conflict of interest.

\section{References}

1. Cheng, F.; Cheng, Z. Research progress on the use of plant allelopathy in agriculture and the physiological and ecological mechanisms of allelopathy. Front. Plant Sci. 2015, 6, 1020. [CrossRef] [PubMed]

2. Patni, B.; Chandra, H.; Mishra, A.P.; Guru, S.K.; Vitalini, S.; Iriti, M. Rice allelopathy in weed management-An integrated approach. Cell. Mol. Biol. 2018, 64, 84-93. [CrossRef] [PubMed]

3. He, H.Q.; Shen, L.H.; Xiong, J.; Jia, X.L.; Lin, W.X.; Wu, H. Conditional genetic effect of allelopathy in rice (Oryza sativa L.) under different environmental conditions. Plant Growth Regul. 2004, 44, 211-218. [CrossRef]

4. Parvez, S.S.; Parvez, M.M.; Fujii, Y.; Gemma, H. Allelopathic competence of Tamarindus indica L. root involved in plant growth regulation. Plant Growth Regul. 2003, 41, 39-148.

5. Dilday, R.H.; Nastasi, P.; Smith, J.R. Allelopathic observations in rice (Oryza sativa L.) to ducksalad (Heteranthera limosa (SW) Willd). Proc. Arkansas Acad. Sci. 1989, 43, 21-22.

6. Fujii, Y. The potential for biological control of paddy and aquatic weeds with allelopathy: allelopathic effect of some rice varieties. In Proceedings of the International Symposium on Biological Control and Integrated Management of Paddy and Aquatic Weeds, Tsukuba, Japan, 19-25 October 1992; pp. 305-320.

7. Garrity, D.P.; Movillon, M.; Moddy, K. Differential weed suppression ability in upland rice cultivars. Agron. J. 1992, 84, 586-591. [CrossRef]

8. Dilday, R.H.; Lin, J.; Yan, W.G. Identification of allelopathy in the USDA-ARS rice germplasm collection. Aust. J. Exp. Agric. 1994, 34, 901-910. [CrossRef] 
9. Olofsdotter, M.; Navarez, D.; Moody, K. Allelopathic potential in rice (Oryza sativa L.) germplasm. Ann. Appl. Biol. 1995, 127, 543-560. [CrossRef]

10. Chung, I.M.; Kim, K.H.; Ahn, J.K.; Ju, H.J. Allelopathic potential evaluation of rice cultivars on Echinochloa crus galli. Korean J. Weed Sci. 1997, 17, 52-58.

11. Chou, C.H. Roles of allelopathy in plant biodiversity and sustainable agriculture. Crit. Rev. Plant Sci. 1999, 18, 609-636. [CrossRef]

12. Chung, I.M.; Ahn, J.K.; Kim, J.T.; Kim, C.S. Assessment of allelopathic potentiality and identification of allelopathic compounds on Korean local rice varieties. Korean J. Crop. Sci. 2000, 45, 44-49.

13. Ahn, J.K.; Chung, I.M. Allelopathic potential of rice hulls on germination and seedling growth of barnyardgrass. Agron. J. 2000, 92, 1162-1167. [CrossRef]

14. Chung, I.M.; Ahn, J.K.; Yun, S.J. Identification of allelopathic compounds from rice (Oryza sativa L.) straw and their biological activity. Can. J. Plant Sci. 2001, 81, 815-819. [CrossRef]

15. Chung, I.M.; Ahn, J.K.; Yun, S.J. Assessment of allelopathic potential of barnyardgrass (Echinochloa crus-galli) on rice (Oryza sativa L.) cultivars. Crop Prot. 2001, 20, 921-928. [CrossRef]

16. Ahn, J.K.; Hahn, S.J.; Kim, J.T.; Khanh, T.D.; Chung, I.M. Evaluation of allelopathic potential among rice (Oryza sativa L.) germplasm for control of Echinochloa crus-galli P. Beauv in the field. Crop Prot. 2005, 24, 413-419. [CrossRef]

17. Jensen, L.B.; Courtis, B.; Shen, L.S.; Li, Z.K.; Olofsdotter, M.; Mauleon, R.P. Locating genes controlling allelopathic effects against barnyardgrass in upland rice. Agron. J. 2001, 93, 21-26. [CrossRef]

18. Parvez, S.S.; Parvez, M.M.; Nishihara, E.; Gemma, H.; Fujii, Y. Tamarindus indica L. leaf is a source of allelopathic substance. Plant Growth Regul. 2003, 40, 107-115. [CrossRef]

19. Khan, A.H.; Vaishya, R.D. Allelopathic effects of different crop residues on germination and growth of weeds. In Proceedings of the First National Symposium on Allelopathy in Agroecosystem (Agriculture \& Forestry), CCS Haryana Agricultural University, Hisar, India, 12-14 February 1992; Tauro, P., Narwal, S.S., Eds.; Indian Society of Allelopathy: Hisar, India, 1992; pp. 59-60.

20. Jafari, L.; Ghadiri, H.; Moradshahi, A. Allelopathic potential of rice (Oryza sativa L.) cultivars on barnyard grass (Echinochloa crus-galli). J. Agric. Sci. Technol. B 2011, 1, 853-864.

21. Ashry, M.A.; Zein, A.A.; El-Nady, M.F.; Abdel-Dayem, Sh.M. Effect of potential allelopathic Egyptian rice cultivars against Echinochloa crus-galli and Echinochloa colona. J. Plant Prot. Path. 2012, 3, 629-644.

22. Kaloumenos, N.S.; Chatzilazaridou, S.L.; Mylona, P.V.; Polidorosd, A.N.; Eleftherohorinos, I.G. Target-site mutation associated with cross-resistance to ALS-inhibiting herbicides in late watergrass (Echinochloa oryzicola Vasing.). Pest Manag. Sci. 2013, 69, 865-873. [CrossRef]

23. Wilson, M.J.; Norswrthy, J.K.; Scott, R.C.; Gbur, E.E. Program approaches to control herbicide resistant barnyardgrass (Echinochloa crus-galli) in Midsouthern United States rice. Weed Technol. 2014, 25, 39-46. [CrossRef]

24. Bajwa, A.A.; Jabran, K.; Shahid, M.; Ali, H.H.; Chauhan, B.S.; Ehsanullah. Eco-biology and management of Echinochloa crus-galli. Crop Prot. 2015, 75, 151-162. [CrossRef]

25. Alam, M.A.; Hakim, M.A.; Juraimi, A.S.; Rafii, M.Y.; Hasan, M.M.; Aslani, F. Potential allelopathic effects of rice plant aqueous extracts on germination and seedling growth of some rice field common weeds. Ital. J. Agron. 2018, 13, 1066. [CrossRef]

26. Bi, H.H.; Zeng, R.S.; Su, L.M.; An, M.; Luo, S.M. Rice allelopathy induced by methyl jasmonate and methyl salicylate. J. Chem. Ecol. 2007, 33, 1089-1103. [CrossRef] [PubMed]

27. Lu, H.; Greenberg, J.T.; Holuigue, L. Editorial: Salicylic acid signaling networks. Front. Plant Sci. 2016, 7, 238. [CrossRef]

28. Turner, J.G.; Ellis, C.; Evoto, A. The jasmonate signal pathway. Plant Cell 2002, 14, 153-164. [CrossRef]

29. Lu, H. Dissection of salicylic acid-mediated defense signaling networks. Plant Signal. Behav. 2009, 4, 713-717. [CrossRef]

30. An, Y.; Shen, Y.B.; Wu, L.J.; Zhang, Z.X. A change of phenolic acids content in poplar leaves induced by methyl salicylate and methyl jasmonate. J. For. Res. 2006, 17, 107-110. [CrossRef]

31. Green, T.; Rogers, S.; Franzen, A.; Gentry, R.A. critical review of the literature to conduct a toxicity assessment for oral exposure to methyl salicylate. Crit. Rev. Toxicol. 2017, 47, 98-120. [CrossRef]

32. Patni, B.; Guru, S.K. Morphophysiological and biochemical parameters associated with competitive ability of rice genotypes against weeds. Indian J. Plant Physiol. 2012, 17, 215-223. 
33. Johnson, D.E.; Dingkuhn, M.; Jones, M.P.; Mahamane, M.C. The influence of rice plant type on the effect of weed competition on Oryza sativa and Oryza glaberrima. Weed Res. 1998, 38, 207-216. [CrossRef]

34. Mohammadi, G.R. Alternative weed control methods: A review. In Weed and Pest Control-Conventional and New Challenges, 1st ed.; Soloneski, S., Larramendy, M., Eds.; InTech: London, UK, 2013; pp. 117-159.

35. Dass, A.; Shekhawat, K.; Choudhary, A.K.; Sepat, S.; Singh Rathore, S.; Mahajan, G.; Singh Chauhan, B. Weed management in rice using crop competition-A review. Crop Prot. 2017, 95, 45-52. [CrossRef]

36. Chung, I.M.; Kim, K.H.; Ahn, J.K.; Lee, S.B.; Kim, S.H.; Hahn, S.J. Comparison of allelopathic potential of rice leaves, straw, and hull extracts on barnyardgrass. Agron J. 2003, 95, 1063-1070. [CrossRef]

37. Jung, W.S.; Kim, K.H.; Ahn, J.K.; Hahn, S.J.; Chung, I.M. Allelopathic potential of rice (Oryza sativa L.) residues against Echinochloa crus galli. Crop Prot. 2004, 23, 211-218. [CrossRef]

38. Awan, T.H.; Lim, C.A.A.; Ahmed, S.; Safdar, M.E.; Chauhan, B.S. Weed-competitive ability of a hybrid and an inbred rice cultivar in managing Ischaemum rugosum in fry-seeded rice. Pak. J. Agric. Sci. 2018, 55, 739-748.

39. Wang, R.L.; Liu, S.W.; Xin, X.W.; Chen, S.; Peng, G.X.; Su, Y.J.; Song, Z.K. Phenolic acids contents and allelopathic potential of 10-cultivars of alfalfa and their bioactivity. Allelopath. J. 2017, 40, 63-70. [CrossRef]

40. Li, Z.H.; Wang, Q.; Ruan, X.; Pan, C.D.; Jiang, D.A. Phenolics and plant allelopathy. Molecules 2010, 15, 8933-8952. [CrossRef]

41. Bravo, H.R.; Copaja, S.V.; Lamborot, M. Phytotoxicity of phenolic acids from cereals. In Weed and Pest Control-Conventional and New Challenges, 1st ed.; Soloneski, S., Larramendy, M., Eds.; InTech: London, UK, 2013; pp. 37-49.

42. Iriti, M.; Faoro, F. Chemical diversity and defence metabolism: how plants cope with pathogens and ozone pollution. Int. J. Mol. Sci. 2009, 10, 3371-3399. [CrossRef]

(C) 2019 by the authors. Licensee MDPI, Basel, Switzerland. This article is an open access article distributed under the terms and conditions of the Creative Commons Attribution (CC BY) license (http://creativecommons.org/licenses/by/4.0/). 